\title{
The influence of depression, level of functioning in everyday life, and illness acceptance on quality of life in patients with Parkinson's disease: a preliminary study
}

\author{
This article was published in the following Dove Press journal: \\ Neuropsychiatric Disease and Treatment \\ 21 March 2017 \\ Number of times this article has been viewed
}

\author{
Joanna Rosińczuk \\ Aleksandra Kołtuniuk \\ Department of Nervous System \\ Diseases, Faculty of Health Science \\ at Wrocław Medical University, \\ Wrocław, Poland
}

\begin{abstract}
Background: Parkinson's disease (PD) is the second most common neurodegenerative disorder after Alzheimer's disease, and its incidence will increase as the global population ages. Due to the multitude of symptoms, this disease clearly has a significant impact on decreasing quality of life for those with PD. We aimed to evaluate the effect of selected variables on quality of life in people with idiopathic PD treated pharmacologically.
\end{abstract}

Materials and methods: This study was conducted among 50 patients with PD aged 47-85 years. The diagnostic survey method was applied to collect data with the use of the authors' questionnaire and standardized questionnaires, including, Parkinson's Disease Questionnaire (PDQ), Beck Depression Inventory, Instrumental Activities of Daily Living Scale, and Acceptance of Illness Scale. The results were statistically analyzed.

Results: Analysis of the study material showed that people who were more self-reliant were characterized by lower intensity of depressive symptoms ( $\rho=-0.567, P=0)$, were more likely to accept their illness $(\rho=0.611, P=0)$, and assessed quality of life better in each of the studied domains of the PDQ. Illness acceptance correlated with the occurrence of depressive symptoms ( $\rho=-0.567, P=0$ ) and significantly affected quality of life.

Conclusion: Factors such as depression, disease acceptance, and functional capacity have a significant impact on the subjective assessment of quality of life in patients with PD. Evaluation of these factors should be taken into account in the therapeutic process, to minimize their negative impact on quality of life in patients with PD.

Keywords: quality of life, Parkinson's disease, PDQ-39, IADL, BDI, AIS

\section{Introduction}

Parkinson's disease (PD) is the second most common neurodegenerative disorder of the central nervous system, is difficult to cure, no treatment is sufficiently effective, ${ }^{1}$ and its incidence continues to increase with the aging global population. Currently, it is estimated that in Europe, there are over 1 million people diagnosed with PD, and globally about 5 million. ${ }^{2}$ Considering the growing population of elderly people in Europe, it is forecast that the number of patients with PD will double by 2030, thus posing a serious challenge for the entire health care system. ${ }^{3,4}$

An extensive loss of dopaminergic neurons in the substantia nigra of the midbrain, which plays a crucial role in the etiopathogenesis of the disease, leads to drastic dopamine deficiency in the striatum. Its deficiency is the cause of cardinal symptoms, such as resting tremor, bradykinesia, rigidity, muscle stiffness, postural instability, stooped
Correspondence: Aleksandra Kołtuniuk
Department of Nervous System Diseases, Faculty of Health Science at Wrocław Medical University, 5 Bartla Street, 5I-6I8 Wrocław, Poland Email aleksandra.koltuniuk@umed.wroc.pl 
posture of the body, and freezing gait. Additional symptoms of the disease include hyposmia (impaired sense of smell), gastrointestinal disorders, impaired mental function (depression, anxiety, psychosis), sleep disorders, and dysphagia. ${ }^{5,6}$

Studies and meta-analyses have concluded that the cause of PD in the vast majority of cases (up to 90\%) is not known. ${ }^{1,7,8}$ In contrast, the underlying cause in $10 \%$ of cases has been confirmed to originate in genetic disorders, family history, toxic effects of exogenous and endogenous factors, exposure to pesticides, pollution, and improper lifestyle.

Studies have shown that PD undoubtedly leads to deterioration in quality of life in patients suffering from it, mainly due to the presence of a multitude of symptoms; ${ }^{6,9}$ therefore, currently it is a priority to carry out ongoing analyses of quality of life to monitor symptoms and applied treatment more efficiently, allocate financial resources properly to provide optimal patient care, and search for areas of deficit for improvement. ${ }^{10-12}$ Analysis of factors that additionally affect quality of life in patients with PD will allow more effective measures to be taken, aimed at improving functioning in daily life and general quality of life.

The aim of this study was to assess the influence of selected variables on quality of life in people with idiopathic PD treated pharmacologically. The following hypotheses were formulated:

- appearance of symptoms of depression have a negative impact on assessment of quality of life;

- acceptance of the disease positively correlates with subjective assessment of quality of life;

- self-reliant persons better assess quality of life.

\section{Materials and methods}

The study involved 50 patients diagnosed with PD and treated only pharmacologically, being members of an association supporting people with PD. Inclusion criteria were confirmed diagnosis of PD based on medical records, age 40-90 years, and no diagnosis of depression before the diagnosis of PD. Exclusion criteria were secondary parkinsonism caused by organic disease or brain damage, no confirmed diagnosis of PD, and inability to fill out the survey form for mental reasons, eg, disorientation.

The majority of patients were male (52\%), aged 61-70 years $(48 \%)$, residents of cities with more than 100,000 inhabitants (42\%), married (66\%), with secondary education $(52 \%)$, retired $(60 \%)$, living together with the family (44\%), and had been suffering from PD for 6-10 years (46\%) (Table 1). All participants were informed of the study's purpose and course and the possibility of withdrawal from participation at every stage. The research project was approved by the Bioethics Committee of Wrocław Medical University (KB 534/2016). All procedures performed in studies involving human participants were in accordance with the ethical standards of the committee and with the 1964 Declaration of Helsinki and its later amendments or comparable ethical standards. Written informed consent was obtained from all individual participants included in the study.

The diagnostic survey method was applied for the purposes of this study, with the use of the authors' questionnaire and standardized questionnaires, ie, Parkinson's Disease Questionnaire (PDQ)-39, ${ }^{13}$ Beck Depression Inventory (BDI), ${ }^{14}$ Instrumental Activities of Daily Living (IADL) scale, ${ }^{15}$ and Acceptance of Illness Scale (AIS). ${ }^{16,17}$

The authors' questionnaire was a survey with questions about sociodemographic data (ie, age, sex, marital status, place of residence, education, professional activity, material status, managing household), duration of illness, type of medication administered due to $\mathrm{PD}$, if a person had been treated for depression before the diagnosis of $\mathrm{PD}$, and if a person had had any surgery to lessen the symptoms of PD.

The PDQ-9 is a versatile tool designed to assess the quality of life and health status of patients with PD. It consists of 39 parameters, arranged in eight scales of issues: mobility (ten items), activities of daily living (six items), emotional well-being (six items), stigma (four items), social support (three items), cognition (four items), communication (three items), and bodily discomfort (three items). Patients answering questions about potential problems had to indicate the frequency with which they experienced problems by selecting a response (scoring $0-4$ ) on a scale of frequency: never $(0)$, occasionally (1), sometimes (2), often (3), and always (4). Response scores range from 0 to 100 . Lower scores reflect a good level of functioning, while higher scores reflect difficulties in functioning. ${ }^{13,18,19}$

The BDI is a screening scale used in the initial diagnosis of depression. The test consists of 21 items relating to different symptoms of depression and is a self-report measure. There are four variants of answers indicating the intensity of symptoms: 0, meaning no symptoms, up to 3 points, meaning very high intensity of a symptom. A respondent chooses the answer that best describes their current mental state. The level of depression is calculated from the sum of scores. The minimum total score is 0 and the maximum 63 points. In practice, scores above 50 points are not obtained, due to the fact that people with severe depression are not able to take the test. The following guidelines are used in interpreting the total score: $0-10$, no depression or lower mood; 11-27, moderate depression; and 28 and above, severe depression. 
Table I Characteristics of the study group

\begin{tabular}{|c|c|c|c|c|c|c|c|c|c|c|c|}
\hline \multirow[t]{2}{*}{ Variables } & \multicolumn{5}{|c|}{ Women $(n=24)$} & \multicolumn{5}{|l|}{ Men $(n=26)$} & \multirow[t]{2}{*}{$P$-value } \\
\hline & Mean & Median & Min & Max & SD & Mean & Median & Min & Max & SD & \\
\hline Duration of illness & 7.2 & 6.5 & 10 & 200 & 40.6 & 80.7 & 80 & 40 & 170 & 40.1 & $0.148^{*}$ \\
\hline Age, years & 64.7 & 67 & 47 & 75 & 7.2 & 67.4 & 67.5 & 54 & 85 & 8.9 & $0.4373^{*}$ \\
\hline Age group, years & & & & & & & & & & & $0.3517 * *$ \\
\hline$\leq 60(n=13)$ & $\mathrm{n}=7$ (29.2\%) & & & & & $\mathrm{n}=6(23.1 \%)$ & & & & & \\
\hline $61-70(n=24)$ & $\mathrm{n}=13(54.2 \%)$ & & & & & $\mathrm{n}=\mathrm{I}(\mathrm{I}(42.3 \%)$ & & & & & \\
\hline$\geq 7 \mid(n=\mid 3)$ & $n=4(16.6 \%)$ & & & & & $n=9(34.6 \%)$ & & & & & \\
\hline Place of residence & & & & & & & & & & & $0.7797^{* *}$ \\
\hline Village or town up to 25,000 residents $(n=12)$ & $n=6(25 \%)$ & & & & & $n=6(23 \%)$ & & & & & \\
\hline City of $25,000-100,000$ residents $(n=17)$ & $\mathrm{n}=7$ (29.2\%) & & & & & $\mathrm{n}=10(38.5 \%)$ & & & & & \\
\hline City of over 100,000 residents $(n=2 I)$ & $\mathrm{n}=\mathrm{II}(45.8 \%)$ & & & & & $\mathrm{n}=10(38.5 \%)$ & & & & & \\
\hline Education & & & & & & & & & & & $0.6175^{* *}$ \\
\hline Basic or vocational $(n=6)$ & $\mathrm{n}=4(16.7 \%)$ & & & & & $\mathrm{n}=2(7.7 \%)$ & & & & & \\
\hline Secondary $(n=26)$ & $\mathrm{n}=12(50 \%)$ & & & & & $\mathrm{n}=\mathrm{I} 4(53.9 \%)$ & & & & & \\
\hline Higher $(n=18)$ & $\mathrm{n}=8(33.3 \%)$ & & & & & $\mathrm{n}=10(38.5 \%)$ & & & & & \\
\hline Marital status & & & & & & & & & & & $0.0019 * *$ \\
\hline Married/in relationship $(n=33)$ & $\mathrm{n}=10(41.7 \%)$ & & & & & $\mathrm{n}=23(88.5 \%)$ & & & & & \\
\hline Widowed $(n=8)$ & $\mathrm{n}=6(25 \%)$ & & & & & $n=2(7.7 \%)$ & & & & & \\
\hline Single/divorced $(n=9)$ & $\mathrm{n}=8(33.3 \%)$ & & & & & $\mathrm{n}=\mathrm{I}(3.8 \%)$ & & & & & \\
\hline Professional activity & & & & & & & & & & & $0.9699 * *$ \\
\hline Employed $(n=9)$ & $\mathrm{n}=4(17.4 \%)$ & & & & & $\mathrm{n}=5(19.2 \%)$ & & & & & \\
\hline Disability pension $(n=10)$ & $\mathrm{n}=5(2 \mathrm{I} .7 \%)$ & & & & & $n=5(19.2 \%)$ & & & & & \\
\hline Retirement pension $(n=30)$ & $\mathrm{n}=14(60.9 \%)$ & & & & & $\mathrm{n}=16(61.6 \%)$ & & & & & \\
\hline Financial status & & & & & & & & & & & $0.9895^{* *}$ \\
\hline $\operatorname{Bad}(n=6)$ & $\mathrm{n}=3(12.5 \%)$ & & & & & $\mathrm{n}=3$ (II.5\%) & & & & & \\
\hline Medium ( $n=29$ ) & $\mathrm{n}=\mathrm{I} 4$ (58.3\%) & & & & & $\mathrm{n}=\mathrm{I} 5(57.7 \%)$ & & & & & \\
\hline Good $(n=15)$ & $\mathrm{n}=7$ (29.2\%) & & & & & $n=8(30.8 \%)$ & & & & & \\
\hline Conducting a household & & & & & & & & & & & $0.0509 * *$ \\
\hline Independently $(n=8)$ & $\mathrm{n}=7$ (29.2\%) & & & & & $\mathrm{n}=\mathrm{I}(3.9 \%)$ & & & & & \\
\hline With a close friend $(n=20)$ & $\mathrm{n}=8(33.3 \%)$ & & & & & $n=12(46.1 \%)$ & & & & & \\
\hline With family $(n=22)$ & $\mathrm{n}=9(37.5 \%)$ & & & & & $n=13(50 \%)$ & & & & & \\
\hline
\end{tabular}

Notes: *Mann-Whitney $U$ test, ${ }^{* *} \chi^{2}$ test.

Abbreviations: max, maximum; min, minimum; SD, standard deviation.

The IADL scale is used to assess the functional capacity of respondents in complex activities of daily living. The following parameters are taken into account: ability to use the phone, reaching remote locations farther than usual walking distance, ability to do shopping and prepare a meal, doing housework independently (cleaning), "do-it-yourself" activities (repairing minor defects), taking medication as prescribed, and managing money. For each of the eight questions, a respondent has a choice of answer: without assistance (3), with a little help (2), and not able to do it (1). The first response indicates the independence/autonomy of a patient in carrying out required tasks in everyday life, the second suggests inability to perform these tasks without the help of other people, and the third indicates dependence on others. The maximum number of points is 24 . The score is significant only in relation to a particular patient, and decline in score over time indicates a deterioration in general condition.

The AIS was adapted to Polish conditions by Juszczyński. ${ }^{17}$ The AIS contains eight statements describing the consequences of the current state of health. In each response, a person evaluates their health on a 5 -point scale, where 1 point means "strongly agree", 2 points "agree", 3 points "do not know", 4 points "do not agree", and 5 points "strongly disagree". A measure of disease acceptance is the sum of points obtained. A final score ranges from 8 to 40 points. Scores of 8-18 indicate a lack of acceptance of disease, 19-29 an average level of acceptance, and 30-40 acceptance of the health situation at a high level. The higher the score, the greater the acceptance of the disease, and thus better adaptation to the constraints imposed by the health situation and lower sense of psychological discomfort associated with the disease. Low scores indicating a lack of acceptance and adaptation to the disease can be manifested through negative emotions.

For all variables, the mean, median, extreme values, and standard deviation were calculated. For qualitative variables, incidence rates (percent) were calculated. The Shapiro-Wilk test was performed to assess the normality of distribution 
for the tested variables. Comparisons of results in terms of sociodemographic characteristics were performed using the Mann-Whitney $U$ test, nonparametric Kruskal-Wallis analysis of variance, and multiple comparisons of mean ranks. Comparison of qualitative variables was performed using $\chi^{2}$ tests. Values of $P<0.05$ were considered statistically significant. In addition, this defined the dependence between selected variables using Spearman's rank-correlation test. Data were analyzed with Statistica 12 (Statistica, Tulsa, OK, USA).

\section{Results}

\section{Functional capability assessment (IADL questionnaire)}

The study showed that the average assessment of functional capacity (IADL) in the study group was 17.94 \pm 4.04 (9-24). It was shown that three-quarters of respondents could independently use the phone, take medications, and manage finances. Unfortunately, only every third respondent could do housework or laundry independently. With a little help, every third respondent could prepare meals or go shopping for groceries on their own. In contrast, $10 \%$ of respondents were not able to reach places beyond a walking distance.

The study results demonstrated statistically significant differences concerning independence in performing activities of daily living with regard to education, marital status, professional activity, managing household, and duration of disease. It was observed that people with primary education ( $P=0.018)$, married $(P=0.028)$, living on a disability pension $(P=0.003)$, assisted in daily activities $(P=0.008)$, and with disease duration over 10 years $(P=0.034)$ had significantly lower autonomy in performing complex activities of daily living than other respondents. It was also shown that those who were more independent (who received a higher score on the IADL scale) were characterized by lower intensity of depressive symptoms (received lower scores on the BDI; $\rho=-0.567, P=0)$ and were more likely to accept their disease $(r=0.611, P=0)$ (Figure 1).

\section{Illness-acceptance assessment (AIS)}

Analysis of data obtained through the AIS showed that the average score for the study group was 25.28 \pm 7.26 . It was shown that $16 \%$ of respondents declared no disease acceptance, $22 \%$ a high level of disease acceptance, and $62 \%$ a moderate acceptance level. It was also shown that the level of acceptance of the disease correlated with occurrence of depressive symptoms $(\rho=-0.567, P=0)$. This means that those

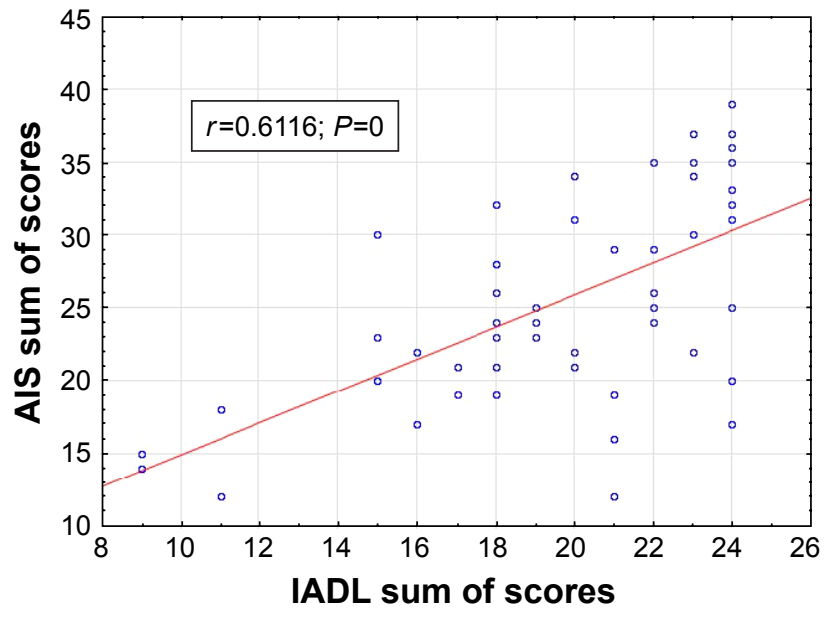

Figure I Correlations between AIS sum of scores and IADL sum of scores. Abbreviations: AIS, Acceptance of IIIness Scale; IADL, Instrumental Activities of Daily Living.

who were likely to accept the disease were characterized by lower intensity of depressive symptoms.

\section{Assessment of depressive symptoms (BDI)}

The conducted studies showed that the average score of depression level in the study group was $13.58 \pm 9.289(0-37)$. Analysis of the study material showed that $44 \%$ of people had no symptoms of depression, $48 \%$ were characterized by depression of moderate severity, and $8 \%$ had symptoms suggestive of severe depression. It was also shown that the occurrence of depressive symptoms in patients with $P D$ was affected by marital status $(P=0.019)$, professional activity $(P=0.005)$, and disease duration $(P=0)$. Widowed people receiving disability pension and suffering for over 10 years were significantly more often diagnosed with depression of moderate severity than others.

\section{Quality-of-life assessment (PDQ-39)}

The average score obtained on the PDQ-39 was 51.36. Detailed data on each domain are presented in Table 2. The results also showed the existence of a strong or very

Table 2 PDQ-39 test results

\begin{tabular}{llll}
\hline PDQ-39 domains & Mean \pm SD & Median & Min-max \\
\hline Mobility & $36.95 \pm 24.652$ & 35 & $0-88$ \\
Activities of daily living & $34.16 \pm 24.947$ & 31.25 & $0-100$ \\
Emotional well-being & $33.752 \pm 21.547$ & 29.2 & $0-88$ \\
Stigma & $32.9 \pm 24.582$ & 31.3 & $0-94$ \\
Social support & $19.504 \pm 20.452$ & 16.7 & $0-83$ \\
Cognition & $29.894 \pm 20.684$ & 25 & $0-81$ \\
Communication & $39.844 \pm 18.914$ & 41.7 & $0-83$ \\
Bodily discomfort & $25.994 \pm 22.118$ & 25 & $0-83$ \\
\hline
\end{tabular}

Abbreviations: PDQ, Parkinson's Disease Questionnaire; SD, standard deviation; min, minimum; max, maximum. 
Table 3 Correlations between PDQ-39 and IADL

\begin{tabular}{lll}
\hline PDQ-39 domains & IADL & \\
\cline { 2 - 3 } & $\rho$ & P-value \\
\hline Mobility & -0.880 & 0 \\
Activities of daily living & -0.698 & 0 \\
Emotional well-being & -0.528 & 0 \\
Stigma & -0.509 & 0 \\
Social support & -0.561 & 0 \\
Cognition & -0.547 & 0 \\
Communication & -0.639 & 0 \\
Bodily discomfort & -0.629 & 0 \\
\hline
\end{tabular}

Abbreviations: PDQ, Parkinson's Disease Questionnaire; IADL, Instrumenta Activities of Daily Living.

strong correlation between the independence level in performing complex activities of daily living and the domains of the questionnaire evaluating quality of life in patients with PD. This proved that people who were more self-reliant assessed quality of life better in each of the studied domains (Table 3).

Moreover, disease acceptance significantly affected quality of life among respondents. Correlations observed in four domains were moderate, and in two domains strong negative correlations between the results of the AIS and the PDQ-39 were observed. This means that people are more likely to accept the illness and the resulting difficulties and better assessed quality of life in the mobility domain $(\rho=-0.544$, $P=0)$, activities of daily living $(\rho=-0.464, P=0.001)$, family support $(\rho=-0.385, P=0.006)$, cognitive function $(\rho=-0.532$, $P=0$ ), communication $(\rho=-0.483, P=0)$, and bodily discomfort $(\rho=-0.442, P=0.001)$.

Analysis of the study material also revealed the existence of the impact of depressive symptoms on quality of life in

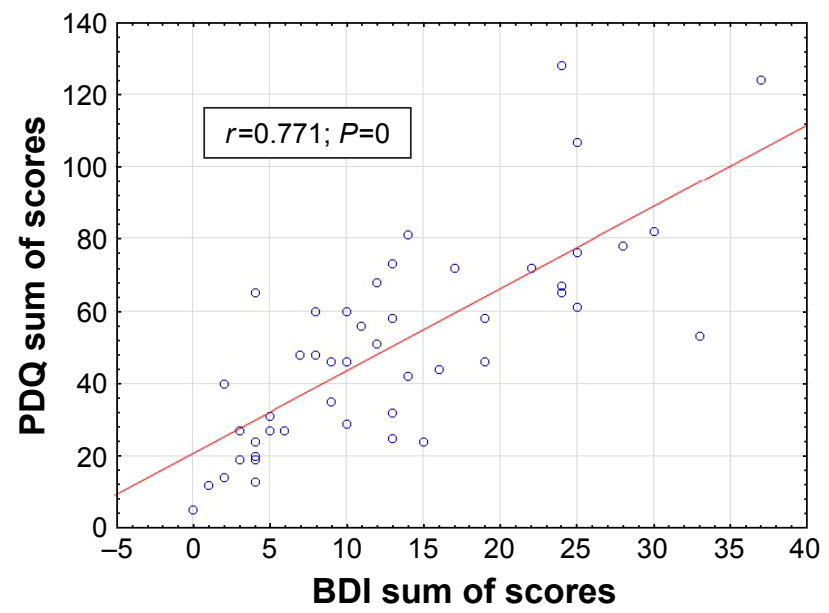

Figure 2 Correlations between PDQ sum of scores and BDI sum of scores. Abbreviations: PDQ, Parkinson's Disease Questionnaire; BDI, Beck Depression Inventory. patients with PD. The occurrence of more severe depressive symptoms was associated with worse general quality of life and low quality of life in different domains (Figure 2).

\section{Discussion}

PD is characterized by a variety of symptoms that have a huge impact on the daily functioning of an affected person. ${ }^{20}$ Therefore, one of the objectives in the treatment of PD should be to reduce the negative impact of symptoms on the daily functioning of patients, and thus also on their quality of life. ${ }^{21}$ However, sometimes a properly applied therapy fails to improve quality of life in patients, due to other factors, eg, mental condition, economic status, acceptance level of the disease, and related limitations.

AIS data showed that the average score for the study group was $25.28 \pm 7.26$. Similar results were obtained by Kurpas et $\mathrm{al}^{22}$ among patients with neurological diseases and Kowalska et $\mathrm{al}^{23}$ among elderly patients hospitalized in a rehabilitation center for chronic diseases of old age, ie, osteoarthritis and PD. Studies have also confirmed a statistically significant correlation between the functional status of elderly patients and stroke survivors and disease acceptance. ${ }^{23,24}$ Kowalska et al ${ }^{24}$ also showed the existence of a stronger correlation between the severity of depressive symptoms and disease acceptance in stroke patients: more severe symptoms of depression were associated with poorer acceptance of the disease and its limitations, which was confirmed in this study.

In the present study, the average score obtained on the BDI was 13.58. Similar results have also been obtained by other authors. ${ }^{25,26}$ However, in Lorencowicz et al, ${ }^{27}$ the average score on the BDI for the study group was significantly lower. Rana et $\mathrm{al}^{28}$ showed that single patients suffering from PD more often experience depression than patients with PD who are married, which was also confirmed in our study. Seiler et $\mathrm{al}^{29}$ showed that a satisfying relationship with a partner may reduce the risk of depression in patients with PD.

Our data showed that people with more severe depression had lower assessment of quality of life. Their functioning in particular domains was also worse. Numerous studies carried out in different countries have confirmed the relationship between depression and deterioration in quality of life in patients with PD. ${ }^{25-27,30-39}$ Our study results thus suggest that improvement in quality of life depends on early diagnosis and proper treatment of depression, which can result in reduction of certain somatic symptoms. . $25,26,35^{2}$

One of the main symptoms of PD is a functional mobility disorder, which as the disease progresses affects functioning 
and performance of precise deliberate movements. ${ }^{40,41}$ People with PD have difficulty in daily functioning. The average score of functional capacity (IADL) was 17.94 \pm 4.04 (9-24), confirming the results of Lorencowicz et al. ${ }^{27}$ The existence of a strong relation between the degree of functionality and quality of life in patients with PD was also confirmed. ${ }^{26,27,37}$ People with worse functioning in daily life show low perception of quality of life. The influence of functional capacity on depressive symptoms was also demonstrated. The study confirmed that the underlying cause of the symptoms of depression is the loss of functional capacity. ${ }^{27}$ Lawrence et $\mathrm{al}^{35}$ suggested that the simultaneous occurrence of depression and reduced functional capacity affect deterioration in quality of life in patients with PD more than the occurrence of each variable separately. Therefore, they recommended applying cognitive behavioral therapy in the treatment of people with PD, which will allow them to accept their limitations and the assistance of others, and thus reduce stress and tension.

In the present study, we demonstrated that patients with PD provide the worst assessment in the domain of communications and mobility, and the average score obtained by respondents on the PDQ-39 was 51.36. Similar results were also obtained by Lorencowicz et $\mathrm{al}^{27}$ in Poland, Tamás et $\mathrm{al}^{42}$ in Hungary, Klepac et $\mathrm{al}^{43}$ in Croatia, and Ziropađa et $\mathrm{al}^{44}$ in Serbia. However, studies conducted in the US ${ }^{45}$ and Australia ${ }^{35,46}$ revealed that the quality of life of their inhabitants with PD was definitely better, taking into account similar average age of patients and duration of disease. These differences may be associated with higher financial expenditure on health care in the US and Australia, as well as providing proper care for the chronically ill.

\section{Limitations}

One of the limitations of our study was the small study group. A sample size of one association was too small for conclusions and generalizations to be representative of all patients. However, this may be a starting point for further research seeking variables significantly affecting quality of life in patients with PD.

\section{Conclusion}

Factors such as depression, disease acceptance, and degree of functional capacity have a significant impact on subjective assessment of quality of life in patients with PD. The evaluation of these factors should be taken into account in the therapeutic process, to minimize their negative impact on quality of life in patients with PD.

\section{Disclosure}

The authors report no conflicts of interest in this work.

\section{References}

1. Singleton AB, Farrer MJ, Bonifati V. The genetics of Parkinson's disease: progress and therapeutic implications. Mov Disord. 2013; 28(1):14-23.

2. Chen JJ. Parkinson's disease: health-related quality of life, economic cost, and implications of early treatment. Am J Manag Care. 2010; 16 Suppl:S87-S93.

3. Dorsey ER, Constantinescu R, Thompson JP, et al. Projected number of people with Parkinson disease in the most populous nations, 2005 through 2030. Neurology. 2007;68(5):384-386.

4. Sławek J. Mam Chorobę Parkinsona: Poradnik dla Nowo Zdiagnozowanych Pacjentów z Choroba Parkinsona [I have Parkinson's disease. Guide for Newly Diagnosed Patients With Parkinson's Disease]. Gdańsk: Via Medica; 2007.

5. Bach JP, Ziegler U, Deuschl G, Dodel R, Doblhammer-Reiter G. Projected numbers of people with movement disorders in the years 2030 and 2050. Mov Disord. 2011;26(12):2286-2290.

6. Coelho M, Ferreira JJ. Late-stage Parkinson disease. Nat Rev Neurol. 2012;8(8):435-442.

7. Bloem BR, Stocchi F. Move for change Part I: a European survey evaluating the impact of the EPDA charter for people with Parkinson's disease: European survey results for people with Parkinson's. Eur $J$ Neurol. 2012;19(3):402-410.

8. Storch A, Schneider CB, Wolz M, et al. Nonmotor fluctuations in Parkinson disease: severity and correlation with motor complications. Neurology. 2013;80(9):800-809.

9. Boland DF, Stacy M. The economic and quality of life burden associated with Parkinson's disease: a focus on symptoms. Am J Manag Care. 2012;18(7 Suppl):S168-S175.

10. Dodel R. Interpreting health economics data in Parkinson's disease. Eur Neurol Rev. 2011;6 (Suppl 1):13-16.

11. Niedzielski A, Humeniuk E, Błaziak P, Fedoruk D. Stopień akceptacji choroby w wybranych chorobach przewlekłych [The degree of disease acceptance in selected chronic diseases]. Wiad Lek. 2007; 60(5-6):224-227.

12. Niedzielski A, Humeniuk E, Tarkowski Z. Poziom akceptacji choroby w wybranych jednostkach chorobowych [The acceptance of disease in selected disease entities]. Fam Med Prim Care Rev. 2005; $7(3): 823$.

13. Jenkinson C, Fitzpatrick R, Peto V, Greenhall R, Hyman N. The Parkinson's Disease Questionnaire (PDQ-39): development and validation of a Parkinson's disease summary index score. Age Ageing. 1997;26(5):353-357.

14. Beck AT, Ward CH, Mendelson M, Mock J, Erbaugh J. An inventory for measuring depression. Arch Gen Psychiatry. 1961;4:561-571.

15. Lawton MP. The functional assessment of elderly people. J Am Geriatr Soc. 1971;19(6):465-481.

16. Felton BJ, Revenson TA. Coping with chronic illness: a study of illness controllability and the influence of coping strategies on psychological adjustment. J Consult Clin Psychol. 1984;52(3):343-353.

17. Juczyński Z. Narzędzia Pomiaru W Promocji I Psychologii Zdrowia [Acceptance of Illness Scale]. Warszawa: Pracownia Testów Psychologicznych Polskiego Towarzystwa Psychologicznego; 2001.

18. Pasek J, Szajkowski S, Suszyński K, Wiaderkiewicz J, Kwiek S. Ocena jakości życia pacjentów ze schorzeniami układu pozapiramidowego po leczeniu stereotaktycznym oraz pozabiegowej rehabilitacji [The quality of life at patients with the extrapyramidal system diseases after stereotactic surgery and rehabilitation]. Ann Acad Med Siles. 2009;63(6):32-39. Polish.

19. Martinez-Martin P, Jeukens-Visser M, Lyons KE, et al. Health-related quality-of-life scales in Parkinson's disease: critique and recommendations. Mov Disord. 2011;26(13):2371-2380. 
20. Rosińczuk-Tonderys J, Mierzwa J, Czarnecka A, Kosmala M. Problemy codziennego funkcjonowania chorych z chorobą Parkinsona w materiale własnym [The problems of daily functioning of patients with Parkinson's disease in own material]. Ann UMCS Sect D Med. 2006;61 (Suppl 17): $328-331$.

21. Opara JA, Brola W, Leonardi M, Błaszczyk B. Quality of life in Parkinson's disease. J Med Life. 2012;5(4):375-381.

22. Kurpas D, Kusz J, Jedynak T, Mroczek B. Stopień akceptacji choroby przewlekłej wśród pacjentów [The acceptance level of chronic diseases among patients]. Fam Med Prim Care Rev. 2012;14(3):396-398. Polish.

23. Kowalska J, Wolny K, Kobylańska M, Wójcik B. Stopień akceptacji choroby a stan funkcjonalny pacjentów starszych przebywających w ośrodku rehabilitacyjnym [The degree of acceptance of illness and functional status among elderly people staying in the rehabilitation center]. Geriatria. 2015;9:3-9. Polish.

24. Kowalska J, Bojko E, Szczepańska-Gieracha J, Rymaszewska J, Rożek-Piechura K. Occurrence of depressive symptoms among older adults after a stroke in the nursing home facility. Rehabil Nurs. 2016; 41(2):112-119.

25. Jiang JL, Tsai ST, Hsieh TC, Lee CW, Lin SH, Chen SY. The impact of motor and depressive symptoms on quality of life in patients with Parkinson's disease. Tzu Chi Med J. 2013;25(3):175-178.

26. Schrag A, Jahanshahi M, Quinn N. What contributes to quality of life in patients with Parkinson's disease? J Neurol Neurosurg Psychiatry. 2000;69(3):308-312.

27. Lorencowicz R, Jasik J, Podkowiński A, Ruchała M, Przychodzka E, Brzozowska A. Wybrane uwarunkowania jakości życia w chorobie Parkinsona. [Selected factors of quality of life with Parkinson's disease] Pielegniarstwo Neurol Neurochir. 2012;1(2):48-57. Polish.

28. Rana AQ, Qureshi AR, Mumtaz A, et al. Associations of pain and depression with marital status in patients diagnosed with Parkinson's disease. Acta Neurol Scand. 2016;133(4):276-280.

29. Seiler S, Perleth B, Gasser T, Ulm G, Oertel W, Ellgring H. Partnership and depression in Parkinson's disease. Behav Neurol. 1992;(2): 75-81.

30. Duncan GW, Khoo TK, Yarnall AJ, et al. Health-related quality of life in early Parkinson's disease: the impact of nonmotor symptoms quality of life in early Parkinson's disease. Mov Disord. 2014;29(2): 195-202.

31. Fereshtehnejad SM, Hadizadeh H, Farhadi F, Shahidi GA, Delbari A, Lökk J. Comparison of the psychological symptoms and disease-specific quality of life between early- and typical-onset Parkinson's disease patients. Parkinsons Dis. 2014;2014:819260.

32. Forsaa EB, Larsen JP, Wentzel-Larsen T, Herlofson K, Alves G. Predictors and course of health-related quality of life in Parkinson's disease. Mov Disord. 2008;23(10):1420-1427.
33. Gallagher DA, Lees AJ, Schrag A. What are the most important nonmotor symptoms in patients with Parkinson's disease and are we missing them? Mov Disord. 2010;25(15):2493-2500.

34. Gozdek L, Laskowska I, Michalak M, Gorzelańczyk E. Ocena jakości życia osób z chorobą Parkinsona [Evaluation of the quality of life in patients with Parkinson's disease]. Pol Forum Psychol. 2007;12(1):51-62. Polish.

35. Lawrence BJ, Gasson N, Kane R, Bucks RS, Loftus AM. Activities of daily living, depression, and quality of life in Parkinson's disease. PLoS One. 2014;9(7):e102294.

36. Sławek J, Derejko M, Lass P. Factors affecting the quality of life of patients with idiopathic Parkinson's disease: a cross-sectional study in an outpatient clinic attendees [sic]. Parkinsonism Relat Disord. 2005;11(7):465-468.

37. Yamanishi T, Tachibana H, Oguru M, et al. Anxiety and depression in patients with Parkinson's disease. Intern Med. 2013;52(5):539-545.

38. Żach M, Friedman A, Sławek J, Derejko M. Quality of life in Polish patients with long-lasting Parkinson's disease. Mov Disord. 2004; 19(6):667-672.

39. Fan JY, Chang BL, Wu YR. Relationships among depression, anxiety, sleep, and quality of life in patients with Parkinson's disease in Taiwan. Parkinsons Dis. 2016;2016:4040185.

40. Rosińczuk-Tonderys J, Mierzwa J. Analiza sprawności ruchowej u chorych na chorobę Parkinsona [The analysis of mobility in patients with Parkinson's disease]. Ann UMCS Sect D Med. 2007;62 (Suppl 18):87-92. Polish

41. Rosińczuk-Tonderys J, Mierzwa J. Funkcjonowanie osób chorych na chorobę Parkinsona poza środowiskiem szpitalnym [The functioning of people with Parkinson's disease outside the hospital environment] Ann UMCS Sect D Med. 2007;62 (Suppl 18):96-110. Polish.

42. Tamás G, Gulácsi L, Bereczki D, et al. Quality of life and costs in Parkinson's disease: a cross sectional study in Hungary. PLoS One. 2014;9(9):e107704. doi:10.1371/journal.pone.0107704.

43. Klepac N, Pikija S, Kraljić T, et al. Association of rural life setting and poorer quality of life in Parkinson's disease patients: a cross-sectional study in Croatia. Eur J Neurol. 2007;14(2):194-198.

44. Ziropađa L, Stefanova E, Potrebić A, Kostić VS. Quality of life in Serbian patients with Parkinson's disease. Qual Life Res. 2009;18(7): 833-839.

45. Kluger BM, Parra V, Jacobson C, et al. The prevalence of fatigue following deep brain stimulation surgery in Parkinson's disease and association with quality of life. Parkinsons Dis. 2012;2012:769506.

46. Lubomski M, Rushworth RL, Lee W, Bertram KL, Williams DR. Sex differences in Parkinson's disease. J Clin Neurosci. 2014;21(9): 1503-1506.
Neuropsychiatric Disease and Treatment

\section{Publish your work in this journal}

Neuropsychiatric Disease and Treatment is an international, peerreviewed journal of clinical therapeutics and pharmacology focusing on concise rapid reporting of clinical or pre-clinical studies on a range of neuropsychiatric and neurological disorders. This journa is indexed on PubMed Central, the 'PsycINFO' database and CAS,

\section{Dovepress}

and is the official journal of The International Neuropsychiatric Association (INA). The manuscript management system is completely online and includes a very quick and fair peer-review system, which is all easy to use. Visit http://www.dovepress.com/testimonials.php to read real quotes from published authors. 